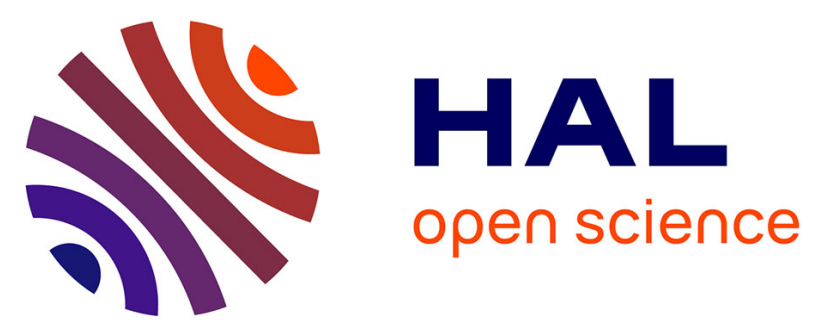

\title{
Development and implementation of eco-genomic tools for aquatic ecosystem biomonitoring: the SYNAQUA French-Swiss program
}

Estelle Lefrancois, Laure Apothéloz-Perret-Gentil, Philippe Blancher, Samuel Botreau, Cécile Chardon, Laura Crepin, Tristan Cordier, Arielle Cordonier, Isabelle Domaizon, Benoit Ferrari, et al.

\section{To cite this version:}

Estelle Lefrancois, Laure Apothéloz-Perret-Gentil, Philippe Blancher, Samuel Botreau, Cécile Chardon, et al.. Development and implementation of eco-genomic tools for aquatic ecosystem biomonitoring: the SYNAQUA French-Swiss program. Environmental Science and Pollution Research, 2018, 25 (34), pp.33858-33866. 10.1007/s11356-018-2172-2 . hal-02916342

\section{HAL Id: hal-02916342 \\ https://hal.inrae.fr/hal-02916342}

Submitted on 17 Aug 2020

HAL is a multi-disciplinary open access archive for the deposit and dissemination of scientific research documents, whether they are published or not. The documents may come from teaching and research institutions in France or abroad, or from public or private research centers.
L'archive ouverte pluridisciplinaire HAL, est destinée au dépôt et à la diffusion de documents scientifiques de niveau recherche, publiés ou non, émanant des établissements d'enseignement et de recherche français ou étrangers, des laboratoires publics ou privés. 


\title{
Development and implementation of eco-genomic tools for aquatic ecosystem biomonitoring: the SYNAQUA French-Swiss program
}

\author{
Estelle Lefrançois ${ }^{1,2}$ (D) - Laure Apothéloz-Perret-Gentil ${ }^{3}$. Philippe Blancher ${ }^{4}$ - Samuel Botreau ${ }^{5} \cdot$ Cécile Chardon $^{2}$. \\ Laura Crepin ${ }^{2} \cdot$ Tristan Cordier $^{3}$ - Arielle Cordonier ${ }^{6} \cdot$ Isabelle Domaizon $^{2} \cdot$ Benoit J. D. Ferrari $^{7}$ - Julie Guéguen ${ }^{2}$. \\ Jean-Christophe Hustache ${ }^{2}$. Louis Jacas ${ }^{2}$. Stephan Jacquet ${ }^{2}$. Sonia Lacroix ${ }^{2}$. Anne-Laurence Mazenq ${ }^{5}$. \\ Alina Pawlowska ${ }^{8} \cdot$ Pascal Perney $^{2} \cdot$ Jan Pawlowski ${ }^{3} \cdot$ Frédéric Rimet $^{2} \cdot$ Jean-François Rubin $^{9} \cdot$ Dominique Trevisan $^{2}$. \\ Régis Vivien ${ }^{7} \cdot$ Agnès Bouchez ${ }^{2}$
}

Received: 29 March 2018 / Accepted: 26 April 2018

(C) Springer-Verlag GmbH Germany, part of Springer Nature 2018

\begin{abstract}
The effectiveness of environmental protection measures is based on the early identification and diagnosis of anthropogenic pressures. Similarly, restoration actions require precise monitoring of changes in the ecological quality of ecosystems, in order to highlight their effectiveness. Monitoring the ecological quality relies on bioindicators, which are organisms revealing the pressures exerted on the environment through the composition of their communities. Their implementation, based on the morphological identification of species, is expensive because it requires time and experts in taxonomy. Recent genomic tools should provide access to reliable and high-throughput environmental monitoring by directly inferring the composition of bioindicators' communities from their DNA (metabarcoding). The French-Swiss program SYNAQUA (INTERREG FranceSwitzerland 2017-2019) proposes to use and validate the tools of environmental genomic for biomonitoring and aims ultimately at their implementation in the regulatory bio-surveillance. SYNAQUA will test the metabarcoding approach focusing on two bioindicators, diatoms, and aquatic oligochaetes, which are used in freshwater biomonitoring in France and Switzerland. To go towards the renewal of current biomonitoring practices, SYNAQUA will (1) bring together different actors: scientists, environmental managers, consulting firms, and biotechnological companies, (2) apply this approach on a large scale to demonstrate its relevance, (3) propose robust and reliable tools, and (4) raise public awareness and train the various actors likely to use these new tools. Biomonitoring approaches based on such environmental genomic tools should address the European need for reliable, higher-throughput monitoring to improve the protection of aquatic environments under multiple pressures, guide their restoration, and follow their evolution.
\end{abstract}

Keywords Metabarcoding $\cdot$ Bioindication $\cdot$ Water quality assessment $\cdot$ Diatoms $\cdot$ Aquatic oligochaetes

Responsible editor: Philippe Garrigues

Estelle Lefrancois

estellelefrancois82@gmail.com

Eco-in'Eau, 34980 Montferrier sur Lez, France

2 UMR CARRTEL, INRA, USMB, 74200 Thonon-les-Bains, France

3 Département de Génétique et Evolution, Université de Genève, 1205 Geneva, Switzerland

4 Philippe Blancher, 69230 Saint-Genis-Laval, France
5 ASTERS Conservatoire D'Espaces Naturels De Haute-Savoie, 74370 Pringy, France

6 Service de l'Ecologie de l'Eau, République et Canton de Genève, 1211 Geneva, Switzerland

7 Swiss Centre for Applied Ecotocicology (Ecotox Centre) EAWAG-EPFL, 1015 Lausanne, Switzerland

8 ID-GENE Ecodiagnostics, Campus Biotech Innovation Park, 1202 Geneva, Switzerland

9 Maison de la Rivière, 1131 Tolochenaz, Switzerland 


\section{Introduction}

The use of a resource or an ecosystem, such as water bodies, usually generates alterations. These alterations can be inputs of nutrients, organic matter, or toxic components via human activities or changes in the hydromorphology (Carpenter et al. 2011). Nowadays, the impairment of freshwater systems and their aquatic biodiversity is recognized and several attempts and legal frameworks exist in order to protect and/or rehabilitate these ecosystems (Vörösmarty et al. 2010).

In Europe, the water quality assessment has been ruled by EU-Water Framework Directive (WFD, European Commission 2000) since its adoption in October 2000. Biomonitoring of rivers and lakes has been applied for years according to the requirements of the WFD in France and the Système modulaire gradué (Liechti et al. 1998) in Switzerland. These regulations brought several essential principles that radically changed the way of managing the water quality assessment. In particular, not only the physicochemical status but also the ecological status of water bodies is assessed through bioindicators as diatoms, oligochaetes, macroinvertebrates, aquatic plants, or fish. The advantage of bioindicators is that the biota can predict the cumulative impact of several pressures and integrates the environmental fluctuations (Holt and Miller 2011). This ecological approach, which has become central, has been a huge step towards a relevant water quality assessment but presents some limitations.

Conventional biomonitoring methods are time-consuming, require high taxonomical expertise, and remain error-prone. Moreover, their standardization is very challenging. In that context, the analysis of bioindicator communities with genomic methods such as DNA metabarcoding (Taberlet et al. 2012) could tackle most of the conventional method limitations, bring innovative solutions, and enable the investigation of prokaryote and eukaryote biodiversity present in environmental samples (Creer 2010). This new approach based on DNA-based identification of taxa, coupled with high-throughput DNA sequencing on nextgeneration sequencing platforms, has been named "Biomonitoring 2.0" by Baird and Hajibabei (2012). That's why scientists from INRA (France) and Geneva University (Switzerland) with expertise in aquatic biomonitoring and DNA metabarcoding decided to join forces to develop and implement such genomic methods. The 2014-2020 Interreg France-Switzerland cooperation program gives them the opportunity to achieve this goal by supporting the SYNAQUA project.

The project as well as preliminary results was presented during the 6th meeting of the INRA Ecotox network, in December 2017 in Alixan (France). This highlight research paper aims to precise SYNAQUA objectives, contents, and expected impacts.
Towards a DNA-based biomonitoring of aquatic ecosystems: the SYNAQUA project

\section{Main aims}

One of the innovating aspects of the project is to address scientific and technical issues as well as related socioeconomic aspects. The ultimate aim is to succeed in the novel tool development and implementation while involving in the same project, scientists, future users, and persons who stand to benefit from it.

- At first, the novel genomic technics developed by the scientists of the French and Swiss partners will be applied to assess the ecological status of rivers and Lake Geneva in both countries. Their implementation and results will be compared to those of conventional approaches.

- The second aim of the project is to contribute to the development of the method: determination of the most reliable sampling protocol, test, and validation of DNA barcodes and of the right primers for both bioindicators (diatoms and oligochaetes), validation and development of reference libraries, choice of a stable and efficient HTS (high-throughput sequencing) technology protocol, identification of the best-practice standard work flow to analyze and store data. Eventually, novel eco-genomic indices will be developed.

- Communication and knowledge dissemination campaigns will be implemented in order to raise awareness of genomic method applications among both citizens and professional stakeholders. These actions will promote this French-Swiss territory as an innovative one in the fields of environment preservation and restoration. This highlight should boost the implementation of the novel methods in other territories and countries.

- Environmental stakeholders will be invited to co-build scenarios of implementation of the novel technics during interactive workshops. Most of the implementation issues, from practical to regulatory aspects, should be addressed at a European level.

- Finally, an accurate high-definition cartography of the ecological quality of Lake Geneva coastline will be produced and will constitute a relevant support for further concerted French-Swiss decisions and actions towards protection and restoration of the lake coastline, enlightening the inputs of methods developed in the project.

SYNAQUA is very consistent with the WFD as its main aim is to produce and apply relevant and cost-effective tools that will improve the ecological status of rivers and lakes. The project is as much relevant for Swiss water quality assessment and the novel tools could be easily implemented in Switzerland. 


\section{Project organization}

The SYNAQUA project was launched on January 1, 2017, and should end May 31,2019. It was set up by a consortium of public and private organizations from France and Switzerland. Partners are involved in one or more of the four operational work packages (WP) according to their expertise (Fig. 1). A fifth WP encompasses all management project's tasks as financial and administrative aspects, partners' meeting organization, website creation and moderation, management, and supervision.

Table 1 summarizes the tasks related to each operational work package.

The project is supported by 2014-2020 Interreg European cooperation program promoting the exchange of experience and the transfer of good practices between actors at all levels in Europe. The French-Swiss project is funded by the European regional development fund (ERDF) of up to 393.000 Euros and a Federal grant (150.000 CHF) covering respectively $60 \%$ of the French total cost and $29 \%$ of the Swiss total cost. Funding was also provided by Swiss cantons (Valais, Geneva, Vaud) to come to the end of the 1.15 M€ global budget. Financial and administrative aspects are handled at a regional level (Région Bourgogne Franche-Comté in France and Coordination Régionale INTERREG in Switzerland).

The project has also been supported by environmental stakeholders such as French Agency for Biodiversity (AFB), the International Commission for the Protection of Lake Geneva (CIPEL), Association for the Protection of the Lake of Geneva (ASL), Syndicat Intercommunal d'Aménagement du Chablais (SIAC), and Syndicat mixte des affluents du sudouest lémanique (SYMASOL).

\section{From conventional to DNA-based bioassessment}

The water quality assessment includes chemical analysis and bioassessment based on various biological organisms. Even if result interpretation can be difficult, bioassessment enables a temporal integrated evaluation of pollution pressure and measures its impact on aquatic ecosystems. The WFD has largely contributed to favor various bioindicator development and implementation.

Diatoms (Bacillariophyceae) are widely distributed microalgae that have been considered as relevant bioindicators of water quality since more than a century (Kolkwitz and Marson 1908; Rimet 2012). These primary producers present in freshwater biofilms on solid substrates encompass numerous species with various ecological preferences that makes them efficient and widely usable bioindicators. Furthermore, their community composition is related with the water quality of the two past months. Finally, their frustule (siliceous skeleton) provides morphological features that are used to identify them thanks to microscopy.

Many diatom-based indices have been developed in Europe using the Zelinka and Marvan formula (Zelinka and Marvan 1961), which takes into account the pollution optima and tolerance of each taxon in the community sampled. In France, the Biological Diatom Index (BDI, Lenoir and Coste 1996) was set up and used to monitor the watercourses quality. This index was adopted in the framework of the WFD by AFNOR in 2000 with a new version in Avril 2016 (AFNOR 2016). In Switzerland, the Swiss Diatom Index (DI-CH, Hürlimann and Niederhauser 2007) based on the same principle was proposed in order to characterize the biological status of rivers and streams and classify them as established by the Swiss Federal Council in the Waters Protection Ordinance (WPO 1998).

Traditional diatom analysis includes several steps presented on Fig. 2: biofilm sampling, sample treatment (EN 13946, AFNOR 2016), diatom identification at species level, and relative abundance measurement thanks to microscopic observation and taxonomical expertise (EN 14407, (AFNOR 2016). Finally, the specific inventory and the relative abundance of each species allow to calculate the value of a diatom index of ecological quality. The results are expressed as an ecological quality ratio (EQR) which is the quotient between the site metrics value and the reference condition one within the same
Fig. 1 SYNAQUA work packages and major partners (leaders in bold) (FR: French; $\mathrm{CH}$ : Swiss)

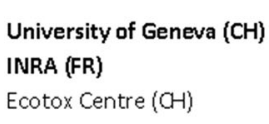

ASTERS-Conservatoire d'espaces naturels HauteSavoie (FR) INRA (FR)

Ecotox Centre $(\mathrm{OH})$

Fondation La maison de la Rivière $(\mathrm{CH})$

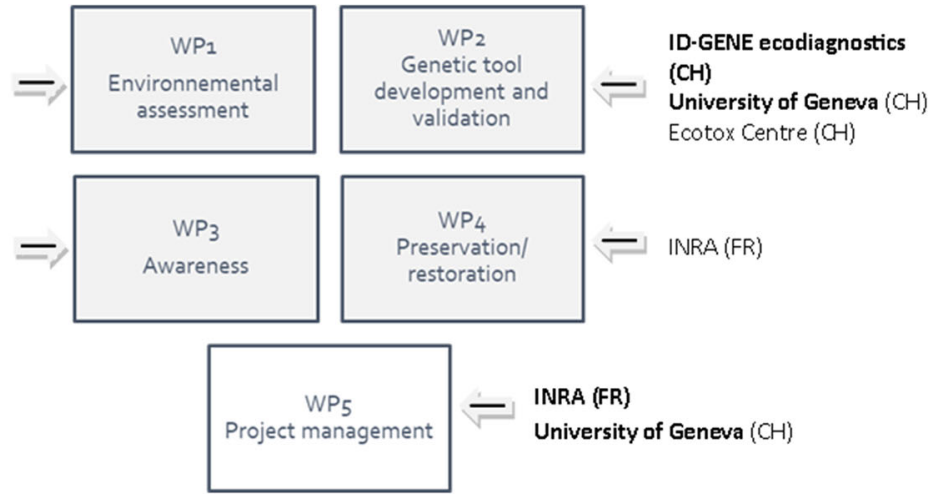


Table 1 Work package tasks

Operational work package

Tasks

WP1 Diatoms

Environmental assessment

Oligochaetes

WP2

Genomic tool development and validation

WP3

Awareness of the genomic tools for biomonitoring

Targeted at primary and secondary-school pupil

Targeted at professional stakeholders

Targeted at citizens
Both traditional and genomic methods will be applied on 126 river sites, chosen among the regulatory biomonitoring network in France (86 samples) and Switzerland (40 samples). Thus, results will be compared.

Sampling and traditional and genomic diatom analysis will be performed on 156 sites of Lake Geneva.

Physicochemical analyses of water samples will be performed in parallel for all sites.

Both traditional and genomic methods will be applied on river and Lake Geneva sites. Physicochemical analyses of sediments (measurement of heavy metals, PCBs, PAHs, organic matter and granulometry) will be performed in parallel.

Development of a high-throughput biomonitoring method: Improvement of reference libraries, validation of genetically based biological indices (sampling, DNA extraction and amplification, sequencing, species assignation, and indices calculation). Standardization of genomic indices. Economical validation and elaboration of a business development plan for Swiss market.

Education tool development, organization of educational trip around Lake Geneva, meeting of scientists, visit of INRA or Geneva University genomic laboratories, organization of workshop on the occasion of various scientific events.

Interactive workshops will be prepared and organized in order to devise realistic and convenient scenarios for stakeholders and regulatory authorities.

Partners will be involved in public events that will take place around Lake Geneva, using various communication resources designed on purpose.

Web site creation: http://www6.inra.fr/synaqua/

WP1 results will enable to set up a high-resolution cartography of the ecological quality of Lake Geneva coastline. This cartography should support decision-makers to focus on at-risk sites and support them in initiating concerted action plan of preservation/restoration. hydroecoregion (HER: homogeneous areas characterized by similar climate, geology, and topography) (Coste et al. 2009; Wasson et al. 2002).

Aquatic oligochaetes are an important group of freshwater benthic invertebrates, abundant in fine, sandy, and coarse sediments of watercourses and lakes, as well as in the hyporheic zone and groundwater (Vivien et al. 2014; Lafont and Vivier 2006). The group includes a large number of species showing a wide range of tolerance to chemical pollution (Rodriguez and Reynoldson 2011; Lafont 1989).

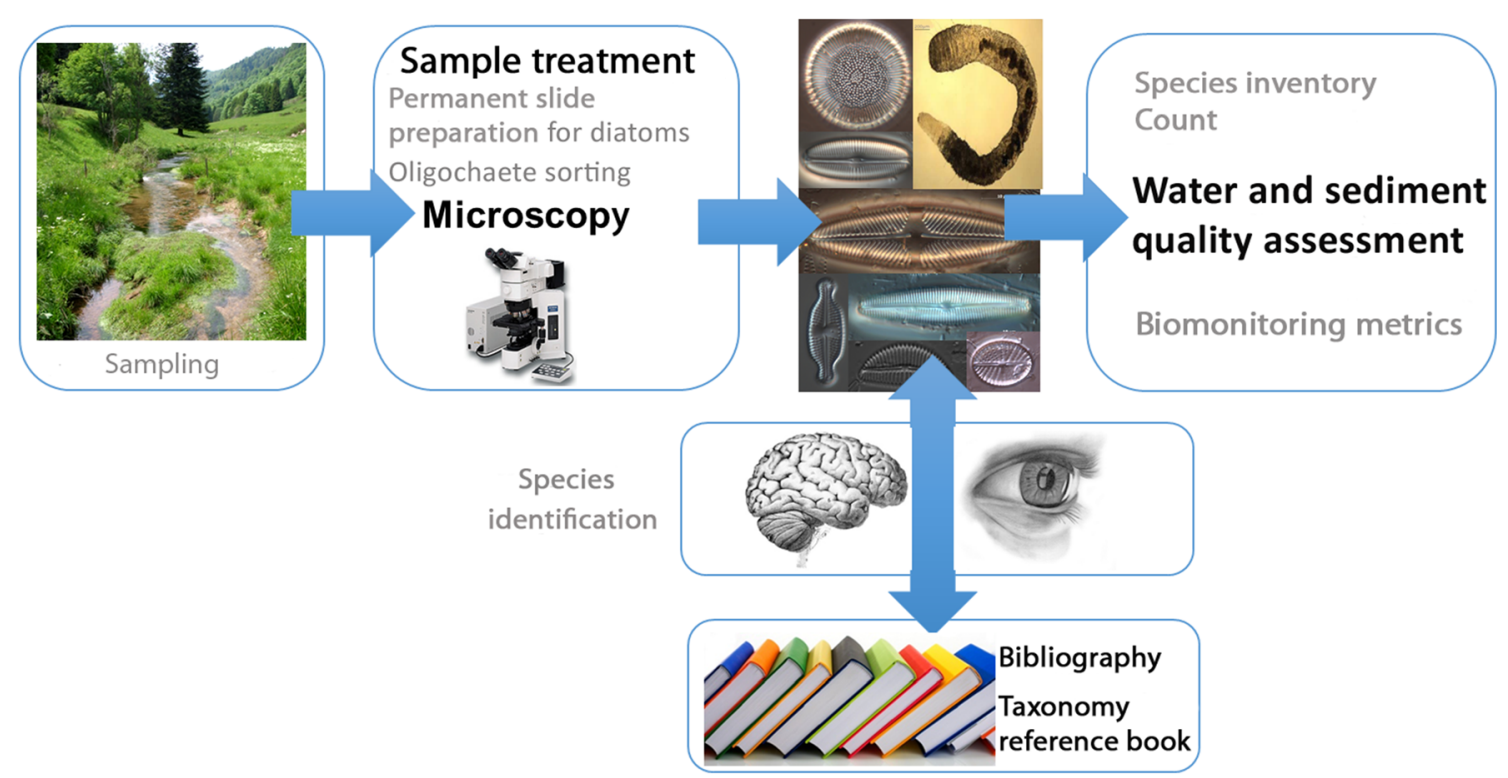

Fig. 2 Conventional method workflow 
Several bioassessment methods based on the analysis of oligochaete assemblages have been developed. Among them, the Oligochaete Index of Sediment Bioindication (IOBS) allows to assess the quality of fine/sandy sediments of watercourses (AFNOR 2016; Prygiel et al. 2000), the Oligochaete Index of Lake Bioindication (IOBL) to assess the quality of fine sediments of lakes (AFNOR 2016; Lafont et al. 2012), and the Functional Traits method to assess simultaneously the quality of the porous matrix (surficial coarse sediments and hyporheic zone) of watercourses and the dynamics of the hydrological exchanges between surface water and groundwater (Lafont and Vivier 2006; Lafont et al. 2010; Vivien et al. 2015a). Oligochaetes have been used for many years in France and in Switzerland to assess the biological quality of rivers and lakes. For example, the IOBS index was applied from 2010 to 2013 by the Water Ecology Service of the canton of Geneva (Switzerland) as part of watercourses quality monitoring program (Vivien et al. 2014; Vivien et al. 2015a) and oligochaetes have been used for decades to assess the ecological quality of Swiss lake sediments (Lang 1997; Lang 2009).

Traditional oligochaete methodologies comprise several steps (Fig. 2): sediment sieving, oligochaete sorting, mounting of specimens between slide and coverslip, and identification of specimens to the species level (microscopic observation). The number of taxa present in a sample and their abundances (percentages) are used to calculate the indices. For example, the IOBS index, that allows to classify the biological quality of watercourse sediments into 5 classes (from very good to bad), is calculated using the following formula: IOBS = $10{\mathrm{~S} . T^{-1}}$ where $S$ is the total number of taxa per sample and $T$ is the percentage of Tubificids with or without hair setae, whichever is dominant in the sediment sample.

Both conventional methods require a long processing time and a high level of taxonomical expertise to correctly identify the taxonomic composition of the communities. This results in (i) long time lag between sample collection and identification and therefore assessment of the ecological quality, (ii) taxonomical uncertainties and incomplete picture of the community blurring the index quality, and (iii) high dependence on taxonomic expertise which is currently decreasing in Europe (Keck et al. 2017).

Concerning diatoms diagnosis, the involvement of numerous operators, and the constant evolution of the taxonomy also enhance the difficulty to get reliable chronicles. Oligochaetes identification based on morphological features is also very challenging and the morphological approach does not allow to identify the totality of the specimens that are present in a sample for three main reasons. First, an important number of species (in Tubificinae, Lumbriculidae, and Enchytraeidae) can be identified only when the specimens are in a mature state. Secondly, the identification of most species in Lumbriculidae and Enchytraeidae requires dissection, which is too time-consuming to be performed in routine analyses.
Thirdly, many aquatic oligochaetes include cryptic species undetectable morphologically.

For all these reasons, genomic tools are an interesting alternative. The production of DNA-based biotic indices consists of several steps presented in Fig. 3. SYNAQUA will contribute to the validation of these steps for diatoms and aquatic oligochaetes.

- Sampling and sample's preservation using a conservative that preserves DNA, allowing its extraction.

- DNA Extraction using in-house or kit protocols.

- PCR amplification on relevant barcodes using primers specific for each bioindicator. Concerning oligochaetes, a fragment of the mitochondrial COI gene is an effective barcode for segregation between species (Vivien et al. 2017). For diatoms, a fragment of the chloroplast rbcL gene was selected for its efficiency to discriminate among species (Kermarrec et al. 2013).

- Sequencing: Sanger sequencing of specimens of morphospecies is the standard approach in generating large-scale reference libraries of DNA barcodes for bioindicator species. HTS technologies allow to analyze the whole community in environmental samples. Moreover, a large number of environmental samples can be multiplexed and analyzed at the same time in a single sequencing run.

- Species assignation: HTS sequences are clustered into Operational Taxonomic Units (OTUs) according to their sequence similarity. A taxonomic identity is then assigned to these OTUs based on a reference library, producing a taxonomic inventory of the sampled community. This step relies on bioinformatic analyses where computing power and software efficiency are here of the utmost importance to achieve a pertinent assignation.

- Calculation of genetically based biotic indices: Finally, the taxa inventory produced by the molecular identification of species and relative abundance of sequences enable to calculate an index value.

Studies on diatom barcoding have been conducted for 10 years in the partner teams, beginning with the $\mathrm{PhD}$ work of Kermarrec et al. (2012). Previous results have obviously been taken into account in the present project. First, metabarcoding tests on a synthetic community allowed to select rbcL and $18 \mathrm{~S}$ genes as the most efficient to discriminate species among community samples (Kermarrec et al. 2013). An expert reference library specific to diatoms (R-Syst::diatom, (Rimet et al. 2016) has been developed for these genes. This open-access reference library (http://www.rsyst.inra.fr/) is regularly updated and includes only curated diatom barcodes. Short barcodes have been adapted for rbcL (Vasselon et al. 2017) and for 18S V4 region (Apothéloz-Perret-Gentil et al. 2017). Different steps of the molecular work have been explored such as the DNA 


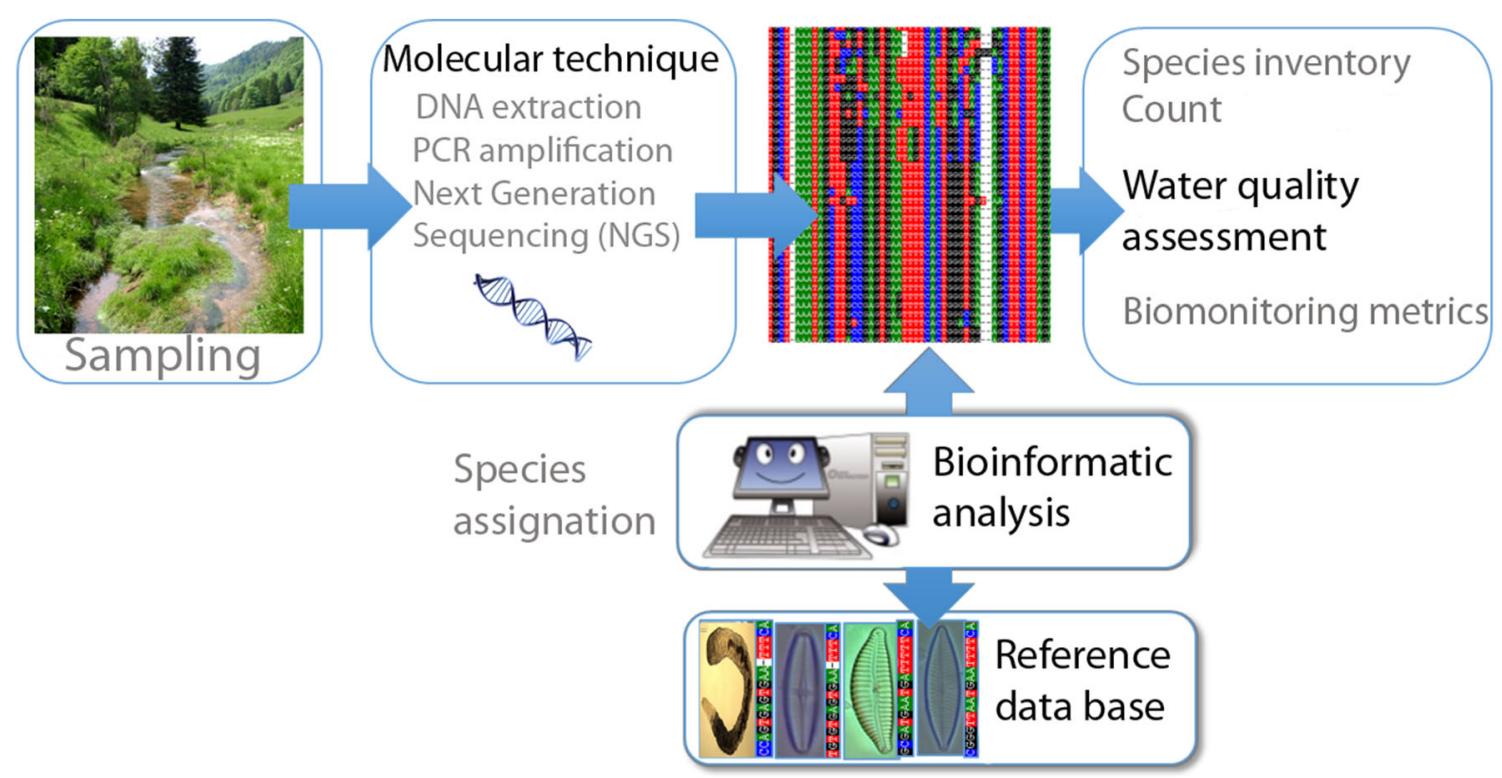

Fig. 3 DNA-based method workflow

extraction (Vasselon et al. 2017) or the accuracy of quantification (Vasselon et al. 2018). The DNA metabarcoding approach on diatoms, after preliminary studies on environmental samples (Kermarrec et al. 2014; Visco et al. 2015), has been recently applied to ecological studies in lakes (Rivera et al. 2018; Rimet et al. 2018) and to river biomonitoring at the scale of monitoring networks (Apothéloz-Perret-Gentil et al. 2017; Vasselon et al. 2017). Based on the high potential of these novel techniques (Keck et al. 2017), some studies suggest deeper changes in biomonitoring approaches (Cordier et al. 2017; Apothéloz-Perret-Gentil et al. 2017).

Two different genomic oligochaete indices are developed as part of the Synaqua project: one based on the HTS analysis of samples composed of genetically tagged specimens and another based on the HTS analysis of samples composed of total sediment. The development of these approaches has required to perform some preliminary studies. First, our COI sequence database of aquatic oligochaetes collected in Switzerland, initiated in 2012 (Vivien et al. 2015b), has been complemented (Vivien et al. 2017). This database covers currently a high number of taxa, which allows the assignation of the large majority of sequences obtained by HTS analysis. Secondly, a method for preserving simultaneously the DNA quality, the density, and the community composition has been developed (Vivien et al. submitted). Thirdly, the COI universal primers $(658 \mathrm{bp})$ used so far to develop the reference library could not be used for metabarcoding as they could not be tagged for multiplexing samples in HTS and they were not able to detect oligochaete species in environmental samples (total sediment and sieved sediments). Specific primers to metazoans, amplifying a fragment of about $300 \mathrm{pb}$, were selected and tested on total and sieved sediment samples: these primers allowed globally a better detection of oligochaete species than the universal primers. In addition, the possibility to use in parallel the $16 \mathrm{~S}$ marker (ribosomal DNA) with specific primers to annelids, susceptible to enable a better detection of oligochaete species in environmental samples than the COI marker, is currently studied.

The novel bioassessment method has many advantages that contribute to make it a disruptive innovation. Compared to conventional methods, genomic tools are fast, cheap (depending on the chosen HTS protocol), and reliable. They enable standardization (no operator bias). Additionally, they offer a new perspective since the large biodiversity of bioindicators in some territory could be assessed. The reliability of biomonitoring methods could be radically enhanced by the choice of more relevant $\mathrm{BQE}$ or the use of additional BQE by the same analysis.

Of course, genomic methods have their specific limits: The need of valid and curated DNA barcode libraries is very significant. Scientists have to reach an agreement about primers, probes and more generally HTS protocol as rapid evolution of HTS techniques and protocols could distort results and prevent to achieve consistent time series. The long-term storage of the huge quantity of generated data (protocol and structure) has also to be taken into account.

Acceptance of the novel technology and potential new indices based on new bioindicators is also very challenging and is directly related to regulatory issues.

\section{Project impacts}

\section{Deliverables}

The deliverables consist in inventories and ecological diagnoses obtained with both genomic and taxonomic methods, their 
comparison, and the cartography of the results. DNA libraries and software that enables to calculate genomic indices will also be produced at the end of the project. Workshops organized with pupils, professional stakeholders, and citizens are part of the deliverables. They should produce scenarios of implementation that could be transmitted to regulatory authorities and decision-makers.

SYNAQUA project is required to bring an added value to economic development within the region and to demonstrate how it will continue after expiration of public financial support. ID-GENE, in collaboration with Swiss partners, has established a business plan that look forward (i) the validation and the commercialization of the genomic methods to improve the management of aquatic natural resources in the Region and (ii) the promotion of a biotechnology competence cluster in the Leman region. The Swiss Federal Office for Environment (OFEV) has already involved ID-GENE/ UNIGE in the national monitoring campaign during the summer 2018.

The project evaluation will focus on economic results and viability in Switzerland while the benefits of the novel methods to bioassessment and restoration project will be appreciated in France.

Finally, publications in peer-reviewed journals and communications of the results in symposiums should allow to circulate information and results concerning the genomic biomonitoring methods.

Scientific communications have already occurred such as the DNAqua-Net kick-off conference in March 2017, the 10th symposium for European freshwater sciences in July 2017, Olomouc (CZ) and, more recently, the environmental DNA seminar organized by the French Agency for Biodiversity (AFB). All these events are listed on the website of the project (https://www6.inra.fr/synaqua/Communication-Presse) and some of the presentation media are downloadable.

DNAqua-Net program website also offers related publications (http://dnaqua.net/publications/).

\section{Expected impacts}

In addition to scientific progress, SYNAQUA project should be a very efficient conveyor of information. Scientists will have the opportunity to make stakeholders aware of the relevancy and the potential of genomic tools for water/sediment quality assessment.

As a result of the project, the genomic bioassessment methods could enter an operational stage. Thus, Lake Geneva area could be, one more time, a famous innovative territory in the environment preservation and restoration fields as well as in participative actions.

Finally, French-Swiss collaboration should be the first step towards a European standardization of genomic methods which is so important according to the quantity of data that will be produced during large monitoring campaigns.

\section{Conclusion}

SYNAQUA is a very challenging project which should achieve its scientific, technical, and economic objectives in May 2019.

Genomic tool development is currently being taken up at the European level. In particular, the DNAqua-Net Project (Developing new genomic tools for bioassessment and monitoring of aquatic ecosystems in Europe, http://dnaqua.net/) is a European Cooperation in Science \& Technology action (EU COST). Its final objective is to create an international interdisciplinary network of scientists, managers, governmental institutions, manufacturers, and emerging service providers to identify major challenges in DNA-based bioassessment and provide standardized best-practice solutions for biomonitoring European waterbodies (Leese et al. 2016). Many DNAqua-Net objectives are highly consistent with SYNAQUA's: (1) Completion of DNA reference libraries for aquatic bioindicator species at European level, (2) Initiation of pilot projects developing genomic tools in parallel to conventional assessment, (3) Harmonization of knowledge, definition of best-practices, and dissemination towards professional stakeholders and citizens, and (4) Fostering the implementation of DNA-based method for biomonitoring at EU level.

The DNAqua-Net network is gaining expertise on bestpractices for DNA-based tools that should produce guidance to be submitted to the European Committee for standardization (CEN). The goal is to produce common standardized protocols for DNA-based methods for all CEN members (e.g., AFNOR for France and Schweizerische NormenVereinigung for Switzerland) to be used at national levels for bioassessment in Europe. Furthermore, CEN standards could be translated as ISO standards if there is no previous ISO guidance.

Funding information The SYNAQUA project is supported by the European Cross-Border Cooperation Program (Interreg FranceSwitzerland 2014-2020) and has thus received a European (European Regional Development Fund) and a Swiss Federal grant covering respectively $60 \%$ of the French total cost and $29 \%$ of the Swiss total cost. Funding was also provided by Swiss cantons (Valais, Geneva, Vaud).

\section{References}

AFNOR (2016) NF T 90-393 Qualité de l'eau - Echantillonnage, Traitement et Analyse Des Oligochètes Dans Les Sédiments Des Eaux de Surface Continentales. pp.1-14+ annexes 
Apothéloz-Perret-Gentil L, Cordonier A, Straub F, Iseli J, Esling P, Pawlowsk J (2017) Taxonomy-free molecular diatom index for high-throughput EDNA biomonitoring. Mol Ecol Resour 17(6): 1231-1242. https://doi.org/10.1111/1755-0998.1266

Baird D, Hajibabei M (2012) Biomonitoring 2.0: a new paradigm in ecosystem assessment made possible by next-generation DNA sequencing. Mol Ecol 21:2039-2044

Carpenter S, Stanley EH, Vander Zanden MF (2011) State of the world's freshwater ecosystems: physical, chemical, and biological changes. Annu Rev Environ Resour 36:75-99

Cordier T, Esling P, Lejzerowicz F, Visco J, Ouadahi A, Martins C, Cedhagen T, Pawlowski P (2017) Predicting the ecological quality status of marine environments from EDNA metabarcoding data using supervised machine learning. Environ Sci Technol 51(16): 9118-9126. https://doi.org/10.1021/acs.est.7b01518

Coste M, Boutry S, Tison-Rosebery J, Delmas F (2009) Improvements of the Biological Diatom Index (BDI): description and efficiency of the new version (BDI-2006). Ecol Indic 9:621-650. https://doi.org/10. 1016/j.ecolind.2008.06.003

Creer S (2010) Second-generation sequencing derived insights into the temporal biodiversity dynamics of freshwater protists. Mol Ecol 19: 2829-2831

European Commission (2000) Directive 2000/60/EC of the European Parliament and of the council of 23rd October 2000 establishing a framework for community action in the field of water policy. Off $\mathrm{J}$ Eur Communities 327:1-72

Holt EA, Miller SW (2011) Bioindicators: using organisms to measure environmental impacts. Nat Educ Knowl 3(10):8

Hürlimann J, Niederhauser P (2007) Méthodes d'Analyse et d'Appreçiation Des Cours d'Eau. Diatoméés Niveau R (Region); Etat de l'environnement $\mathrm{N}^{\circ}$ 0740. Office Fédéral de l'Environnement, Berne 132p

Keck F, Vasselon V, Tapolczai K, Rimet F, Agnès Bouchez A (2017) Freshwater biomonitoring in the information age. Front Ecol Environ 15(5):266-274. https://doi.org/10.1002/fee.1490

Kermarrec L, Franc A, Rimet F (2014) A next-generation sequencing approach to river biomonitoring using benthic diatoms. Freshw Sci 33:349-363

Kermarrec L, Bouchez A, Rimet F, \& Humbert JF (2012) First evidence of the existence of semi-cryptic species and of a phylogeographic structure in the Gomphonema parvulum (Kützing) Kützing complex (Bacillariophyta). Protist 164:686-705

Kermarrec L, Franc A, Rimet F, Chaumeil P, Humbert JF, Bouchez A, (2013) Next-generation sequencing to inventory taxonomic diversity in eukaryotic communities: a test for freshwater diatoms. Mol Ecol Resour 13(4):607-619

Kolkwitz R, Marson M (1908) Okologie Der Pflanzliche Saprobien. Berichte Der Deutsche Botanische Gesellschaften 26:505-519

Lafont M (1989) Contribution à La Gestion Des Eaux Continentales: Utilisation Des Oligochètes Comme Descripteurs de l'état Biologique et Du Degré de Pollution Des Eaux et Des Sédiments. Thèse de Doctorat ès Sciences, Université de Lyon I

Lafont M, Vivier A (2006) Oligochaete assemblages in the hyporheic zone and coarse surface sediments: their importance for understanding of ecological functioning of watercourses. Hydrobiologia 564: 171-181

Lafont M, Jézéquel C, Vivier A, Breil P, Schmitt L, Bernoud S (2010) Refinement of biomonitoring of urban watercourses by combining descriptive and ecohydrological approaches. Ecohydrol Hydrobiol $10: 3-11$

Lafont M, Tixier G, Marsalek J, Jézéquel C, Breil P, Schmitt L (2012) From research to operational biomonitoring of freshwaters: a suggested conceptual framework and practical solutions. Ecohydrol Hydrobiol 12:9-20
Lang C (1997) Oligochaetes, organic sedimentation, and trophic state: how to assess the biological recovery of sediments in lakes? Aquat Sci 59:26-33

Lang C (2009) Indices Basé Sur Les Oligochètes et Les Chironomes Indiquant La Restauration Écologique Des Sédiments Du Léman. Bulletin de La Société Vaudoise Des Sciences Naturelles 91:283300

Leese F, Altermatt F, Bouchez A, Ekrem T, Hering D, Meissner K, Mergen P, Pawlowski J, Piggott J, Rimet F, Steinke D, Taberlet P, Weigand A, Abarenkov K, Beja P, Bervoets L, Björnsdóttir S, Boets P, Boggero A, Bones A, Borja Á, Bruce K, Bursić V, Carlsson J, Čiampor F, Čiamporová-Zatovičová Z, Coissac E, Costa F, Costache M, Creer S, Csabai Z, Deiner K, DelValls Á, Drakare S, Duarte S, Eleršek T, Fazi S, Fišer C, Flot JF, Fonseca V, Fontaneto D, Grabowski M, Graf W, Guðbrandsson J, Hellström M, Hershkovitz Y, Hollingsworth P, Japoshvili B, Jones J, Kahlert M, Kalamujic Stroil B, Kasapidis P, Kelly M, Kelly-Quinn M, Keskin E, Kõljalg U, Ljubešić Z, Maček I, Mächler E, Mahon A, Marečková M, Mejdandzic M, Mircheva G, Montagna M, Moritz C, Mulk V, Naumoski A, Navodaru I, Padisák J, Pálsson S, Panksep K, Penev L, Petrusek A, Pfannkuchen M, Primmer C, Rinkevich B, Rotter A, Schmidt-Kloiber A, Segurado P, Speksnijder A, Stoev P, Strand M, Šulčius S, Sundberg P, Traugott M, Tsigenopoulos C, Turon X, Valentini A, van der Hoorn B, Várbíró G, Vasquez Hadjilyra M, Viguri J, Vitonytė I, Vogler A, Vrålstad T, Wägele W, Wenne R, Winding A, Woodward G, Zegura B, Zimmermann J (2016) DNAqua-Net: developing new genetic tools for bioassessment and monitoring of aquatic ecosystems in Europe. Res Ideas Outcomes 2:e11321. https://doi.org/10.3897/rio.2.e11321

Lenoir A, Coste M (1996) Development of a practical diatom index of overall water quality applicable to the French National Water Board Network. Use of algae for monitoring rivers, Vol. II. In: Whitton BA, Rott E (Eds.) edition, sec. Studia Student, GmbH

Liechti P, Sieber U, Bundi U, Frutiger A, Hütte M, Peter A, von Blücher U, Willi AP, Göldi C, Kupper U, Meier W, Niederhauser P, (1998) Méthodes d'analyse et d'appréciation des cours d'eau. Système Modulaire Gradué. Informations concernant la protection des eaux $n^{\circ} 26$. Office fédéral de l'environnement, Berne, $\mathrm{p} 43$

Prygiel J, Rosso-Darmet A, Lafont M, Durbec A, Ouddane B (2000) Use of oligochaete communities for assessment of ecotoxicological risk in fine sediment of rivers and canals of the Artois-Picardie Water Basin (France). Hydrobiologia 410:25-37

Rimet F (2012) Recent views on river pollution and diatoms. Hydrobiologia 683:1-24. https://doi.org/10.1007/s10750-0110949-0

Rimet F, Chaumeil P, Keck F (2016) R-Syst::diatom: an open-access and curated barcode database for diatoms and freshwater monitoring. Database 2016:Baw016

Rimet F, Vasselon V, Keszte B, Bouchez A (2018) Do We Similarly Assess Diversity with Microscopy and High-Throughput Sequencing? Case of Microalgae in Lakes. Org Divers Evol 18:51. https://doi.org/10.1007/s13127-018-0359-5

Rivera SF, Vasselon V, Jacquet S, Bouchez A, Ariztegui D, Rimet F (2018) Metabarcoding of Lake Benthic diatoms: from structure assemblages to ecological assessment. Hydrobiologia 807(1):37-51. https://doi.org/10.1007/s10750-017-3381-2

Rodriguez P, Reynoldson TB (2011) The Pollution Biology of Aquatic Oligochaetes. Springer Science+Business Media B.V. 2011. https:// doi.org/10.1007/978-94-007-1718-3_1

Taberlet P, Croissac E, Pompanon F, Brochmann C, Willerslev E (2012) Towards next-generation biodiversity assessment using DNA metabarcoding. Mol Ecol 21(8):2045-2050

Vasselon V, Rimet F, Tapolczai K, Bouchez A (2017) Assessing ecological status with diatoms DNA metabarcoding: scaling-up on a WFD monitoring network (Mayotte Island, France). Ecol Indic 82(November):1-12. https://doi.org/10.1016/j.ecolind.2017.06.024 
Vasselon V, Bouchez A, Rimet F, Jacquet S, Trobajo R, Corniquel M, Tapolczai K, Domaizon I (2018) Avoiding quantification bias in metabarcoding: application of a cell biovolume correction factor in diatom molecular biomonitoring. Methods Ecol Evol 00:1-10. https://doi.org/10.1111/2041-210X.12960

Visco JA, Apothéloz-Perret-Gentil L, Cordonier A, Esling P, Pillet L, Pawlowski J (2015) Environmental monitoring: inferring the diatom index from next-generation sequencing data. Environ Sci Technol 49(13):7597-7605. https://doi.org/10.1021/es506158m

Vivien R, Tixier G, Lafont M (2014) Use of oligochaete communities for assessing the quality of sediments in watercourses of the Geneva area (Switzerland) and Artois-Picardie Basin (France): proposition of heavy metal toxicity thresholds. Ecohydrology \& Hydrobiology $14: 142-151$

Vivien R, Lafont M, Ferrari BJD (2015a) Utilisation Des Communautés d'oligochètes Pour l'évaluation de La Qualité Biologique et Du Fonctionnement Des Cours d'eau : Un Bilan à Partir de Données Genevoises (Suisse). Arch Des Sci 68:105-116

Vivien R, Wyler S, Lafont M, Pawlowski J (2015b) Molecular Barcoding of Aquatic Oligochaetes: Implications for Biomonitoring. PLoS ONE 10(4):e0125485
Vivien R, Holzmann M, Werner I, Pawlowski J, Lafont M, Ferrari BJD (2017) Cytochrome c oxidase barcodes for aquatic oligochaete identification: development of a Swiss reference database. PeerJ 5: e4122. https://doi.org/10.7717/peerj.4122

Vörösmarty CJ, Mcintyre PB, Gessner MO, Dudgeon D, Prusevitch A, Green P, Glidden S et al (2010) Global threats to human water security and river biodiversity. Nature 467:555-561

Wasson JG, Blanc L, Chandesris A, Pella H (2002) Définition Des Hydro-Écoregions de France Métroplolitaine. Approche Regionale de Typologie Des Eaux Courantes et Éléments Pour La Définition Des Peuplements de Référence d'invertébrés. Lyon BEA/LH: Cemagref

WPO (1998) Water Protection Ordinance of 28 October 1998 (814.201). UNECE, Geneve.

Zelinka M, Marvan P (1961) Zur Prazisierung Der Biologischen Klassifikation Des Reinheit Fliessender Gewasser. Arch Hydrobiol 57:389-407 